\title{
Acute Myocardial Infarction. The First Manifestation of Ischemic Heart Disease and Relation to Risk Factors
}

\author{
Waldomiro Carlos Manfroi, Carolina Peukert, Clarissa Bacha Berti, Clarissa Noer, Danielle de Ávila Gutierres, \\ Felipe Theodoro Bezerra Gaspar Carvalho da Silva
}

Porto Alegre, RS - Brazil

\begin{abstract}
Objective - To assess the association between cardiovascular risk factors and acute myocardial infarction as the first manifestation of ischemic heart disease, correlating them with coronary angiographic findings.
\end{abstract}

Methods - We carried out a cross-sectional study of 104 patients with previous acute myocardial infarction, who were divided into 2 groups according to the presence or absence of angina prior to acute myocardial infarction. We assessed the presence of angina preceding acute myocardial infarction and risk factors, such as age $>55$ years, male sex, smoking, systemic arterial hypertension, lipid profile, diabetes mellitus, obesity, sedentary lifestyle, and familial history of ischemic heart disease. On coronary angiography, the severity of coronary heart disease and presence of left ventricular hypertrophy were assessed.

Results - Of the 104 patients studied, $72.1 \%$ were males, $90.4 \%$ were white, $73.1 \%$ were older than 55 years, and $53.8 \%$ were hypertensive. Acute myocardial infarction was the first manifestation of ischemic heart disease in $49 \%$ of the patients. The associated risk factors were systemic arterial hypertension $(R R=0.19 ; 95 \% C I=0.06-0.59$; $P=0.04)$ and left ventricular hypertrophy $(R R=0.27 ; 95 \%$ $C I=0, .8-0.88 ; P=0.03)$. The remaining risk factors were not statistically significant.

Conclusion - Prevalence of acute myocardial infarction as the first manifestation of ischemic heart disease is high, approximately $50 \%$. Hypertensive individuals more frequently have symptoms preceding acute myocardial infarction, probably due to ventricular hypertrophy associated with high blood pressure levels.

Key words: acute myocardial infarction, risk factors

Hospital de Clínicas de Porto Alegre - UFRGS

Mailing address: Waldomiro Carlos Manfroi-Rua Alcides Gonzaga, 330-90480-020 Porto Alegre, RS, Brazil

English version by Stela Maris C. e Gandour
Ischemic heart disease continues to be one of the major causes of death in industrialized countries, atherosclerosis being its etiopathogenic substrate ${ }^{1}$. Several factors related to the severity of the disease were identified as follows: systemic arterial hypertension, smoking, age, sex, diabetes mellitus, the number of arteries impaired, and degree of functional impairment of the left ventricle ${ }^{2}$.

According to the literature, acute myocardial infarction is the first manifestation of ischemic heart disease in approximately $50 \%$ to $70 \%$ of patients ${ }^{3-6}$. It has not yet been established whether any of the risk factors has an independent participation in the instability of the plaque for triggering myocardial infarction as the first manifestation of ischemic heart disease ${ }^{7}$. Acute myocardial infarction with no previous angina has been suggested to be more prevalent in young males, and to relate to impairment of a single vessel and a better clinical evolution ${ }^{8-10}$. Other studies disagree about the importance of these risk factors ${ }^{10}$. Therefore, a controversy persists in regard to several conditions that characterize patients with acute myocardial infarction as the first manifestation of ischemic heart disease.

The objective of this study was to delineate the incidence of acute myocardial infarction as the first manifestation of ischemic heart disease and to investigate the participation of risk factors in patients who experience myocardial infarction as the first manifestation of disease, as compared with other patients with angina preceding myocardial infarction. We also aimed at assessing, from the angiographic point of view, whether a difference in the degree of obstruction exists.

\section{Methods}

We carried out a cross-sectional study of 104 patients with acute myocardial infarction confirmed by clinical, electrocardiographic, and enzymatic methods, who were admitted to the Hemodynamics Unit of the Cardiology Service of the Hospital de Clínicas de Porto Alegre (HCPA), with an indication for undergoing coronary angiography. Through 
application of a standard questionnaire, we obtained data on risk factors for ischemic heart disease, such as systemic arterial hypertension, smoking, obesity, diabetes mellitus, sex, and familial history. Presence or absence of symptoms preceding acute myocardial infarction, such as pain or other equivalent symptoms (arrhythmias, dizziness, fatigue, or dyspnea on exertion) were also assessed through the questionnaire. If pain were present, the following topics were approached: beginning, location, intensity, characteristics (grasp, twinge, burning sensation); irradiation (arms, shoulders, neck, mandible, posterior cervical region, dorsum, ulnar region, and epigastric region); relief conditions (rest, nitrate, ingestion of liquids, changes in position); worsening and triggering conditions (exertion, emotions); and duration of the pain (seconds, 1 to 5 minutes, 5 to 10 minutes, 10 to 20 minutes, and more than 20 minutes). These data were related to the severity and extensiveness of the coronary heart disease, in addition to the presence of collateral circulation, determined through coronary angiography. Hemodynamic and cineangiocardiographic studies were performed with left cardiac catheterization with dissection of the right brachial artery or puncture through the right femoral artery with the patient under local anesthesia (2\% lidocaine). Selective coronary angiography was performed according to the technique of Sones and Sinrey ${ }^{10}$, and Judikins ${ }^{11}$. Cineangiocardiographic films were interpreted by 2 experienced researchers, who ignored the presence or absence of risk factors, and of a previous history of acute myocardial infarction. Hypertrophy was defined using cineventriculographic findings of ventricular wall thickness and echocardiographic findings. To quantify the severity of coronary artery stenoses, we used the degrees of stenosis as follows ${ }^{12}:<50 \%$, severity $=0$; from $50 \%$ to $74 \%$, severity $=1$; from $75 \%$ to $90 \%$, severity $=2$; and $>90 \%$, severity $=3$.

Before undergoing the procedure, the patients were invited to participate in the study and to sign a written informed consent approved by the Committee on Ethics of the Research and Postgraduate Group of the HCPA, authorizing the withdrawal of $10 \mathrm{~mL}$ of blood for later serum lipid analysis. The blood sample collected underwent the following analyses in the Biochemistry Unit of the HCPA: total cholesterol and triglycerides (colorimetric enzymatic method using the Autoanalyser Selectra-Vitaldo, Merck), HDL-C and LDL-C (selective ionic precipitation/colorimetric enzymatic method).

The patients were considered hypertensive when they reported a history of hypertension diagnosed in a medical service where they were treated and when they were on dietary or pharmacological treatment, or both. Smoking was defined as the consumption of at least 5 cigarettes per day for at least 1 year over the last 5 years. The diabetic patients were those with a confirmed diagnosis of diabetes mellitus. Obesity was defined by the Quetelet index, according to the National Institutes of Health Consensus Development ${ }^{13}$. In females, a Queteletindex >27.3 was considered obesity, which in males occurred for values $>27.8$. The limits considered normal in the samples studied were the following: total cholesterol <200 mg/dL, HDL cholesterol >40mg/dL, LDL cholesterol $<130 \mathrm{mg} / \mathrm{dL}$. The cut points for triglycerides were
$<140 \mathrm{mg} / \mathrm{dL}$ for patients 30 years or younger, $<150 \mathrm{mg} / \mathrm{dL}$ for patients from 31 to 40 years, $<160 \mathrm{mg} / \mathrm{dL}$ for patients from 41 to 50 years, and $<160 \mathrm{mg} / \mathrm{dL}$ for patients older than 50 years (according to the standards of the kit used for analysis).

To assess the association between potential risk factors and manifestation of ischemic heart disease, the chisquare test was used with continuity correction (Yates), except for severity (Pearson chi-square) and race (Fischer exact test), in addition to the prevalence rate (relative risk) and $95 \%$ confidence interval. To control confounding and interaction factors, multiple logistic regression was used. The significance level used was $0.05(P<0.05)$. The version 6.0 of the SPSS program was used.

\section{Results}

Of the 104 patients studied, 51 (49\%) had acute myocardial infarction as the first manifestation of ischemic heart disease.

Of the nonhypertensive patients, $64.6 \%$ developed acute myocardial infarction as the first manifestation as compared with $35.4 \%$ of the hypertensive patients $(\mathrm{RR}=$ $0.55 ; 95 \% \mathrm{CI}=0.36-0.83)$. The remaining risk factors did not show statistical significance for the development of acute myocardial infarction as the first manifestation of ischemic heart disease (table I).

In multivariate analysis, the greater prevalence of acute myocardial infarction as the first manifestation of ischemic heart disease in nonhypertensive patients remained statistically significant $(\mathrm{RR}=0.19 ; 95 \% \mathrm{CI}=0.06-0.6)$. The presence of acute myocardial infarction as the first manifestation was less prevalent among patients with myocardial hypertrophy $(\mathrm{RR}=0.27 ; 95 \% \mathrm{CI}=0.08-0.88)$. The remaining factors included in the multivariate analysis, such as diabetes mellitus, smoking, familial history of ischemic heart disease, age, the total cholesterol/HDL ratio, and coronary artery stenosis were not statistically significant (table II).

\begin{tabular}{|c|c|c|c|c|c|}
\hline \multicolumn{6}{|c|}{$\begin{array}{l}\text { Table I-Comparison of risk factors between patients with and without } \\
\text { angina pectoris prior to myocardial infarction - univariate analysis }(N=104)\end{array}$} \\
\hline Variables & $\begin{array}{c}\text { AMI } \\
\text { as the } 1^{\text {st }} \\
\text { manifestation }\end{array}$ & \multirow{2}{*}{$\begin{array}{c}\begin{array}{c}\text { Angina } \\
\text { prior to } \\
\text { AMI }\end{array} \\
53.9\end{array}$} & \multirow{2}{*}{$\begin{array}{c}\begin{array}{c}\text { Relative } \\
\text { risk }\end{array} \\
0.80\end{array}$} & \multirow{2}{*}{$\begin{array}{c}95 \% \mathrm{CI} \\
0.53-1.20\end{array}$} & $\mathrm{P}$ \\
\hline Idade $>55$ anos & 46.1 & & & & 0.4 \\
\hline Male sex $(\%)$ & 78.4 & 66 & 1.40 & $0.84-2.34$ & 0.2 \\
\hline White race $(\%)$ & 94.1 & 86.8 & 1.70 & $0.64-4.41$ & 0.3 \\
\hline Hypertension (\%) & 39.2 & 67.9 & 0.55 & $0.36-0.83$ & 0.006 \\
\hline Diabetes mellitus (\%) & 23.5 & 30.2 & 0.83 & $0.51-1.35$ & 0.6 \\
\hline Smoking (\%) & 35.3 & 41.5 & 0.87 & $0.57-1.32$ & 0.6 \\
\hline Obesity (\%) & 9.8 & 15.1 & 0.76 & $0.37-1.35$ & 0.6 \\
\hline Familial history (\%) & 62.7 & 52.8 & 1.23 & $0.81-1.86$ & 0.4 \\
\hline $\mathrm{FH}$ of $\mathrm{DM}(\%)^{*}$ & 35.3 & 32.1 & 1.07 & $0.71-1.61$ & 0.9 \\
\hline $\mathrm{FH}$ of SAH $(\%)^{*}$ & 41.2 & 43.4 & 0.95 & $0.64-1.42$ & 1 \\
\hline Total cholesterol $>200$ & $0 \quad 29.4$ & 39.6 & 0.78 & $0.50-1.20$ & 0.4 \\
\hline $\mathrm{HDL}<40$ & 90.2 & 73.6 & 1.22 & $0.77-1.93$ & 0.5 \\
\hline $\mathrm{LDL}>130$ & 25.5 & 20 & 1.16 & $0.75-1.77$ & 0.7 \\
\hline LV hypertrophy* & 26.7 & 38 & 0.75 & $0.45-1.24$ & 0.3 \\
\hline history; SAH- systemic & ic arterial $\mathrm{l}$ & ensio & tes mell & $\begin{array}{l}\text { litus; } \mathrm{FH}-\mathrm{fa} \\
\text { t ventricle. }\end{array}$ & nilial \\
\hline
\end{tabular}




\begin{tabular}{|c|c|c|c|c|c|c|}
\hline \multicolumn{7}{|c|}{$\begin{array}{l}\text { Table II - Relation between the presence of risk factors and the } \\
\text { development of acute myocardial infarction as the first manifestation } \\
\text { of ischemic heart disease - multivariate analysis }(\mathrm{N}=104)\end{array}$} \\
\hline Variables & & $\begin{array}{l}\text { AMI as the } 1^{\text {st }} \\
\text { manifestation } \\
\mathrm{N}(\%)\end{array}$ & $\begin{array}{r}\text { Total of } \\
\text { patients }\end{array}$ & $\begin{array}{c}\text { Relative } \\
\text { risk }\end{array}$ & $95 \% \mathrm{CI}$ & $\mathrm{P}$ \\
\hline \multicolumn{2}{|l|}{ Age $>55$ years } & $35(46.1)$ & 76 & 1.04 & $0.99-1.10$ & 0.09 \\
\hline \multirow{3}{*}{$\begin{array}{l}<55 \text { year } \\
\text { Hypertension: }\end{array}$} & & $16(57.1)$ & 28 & & & \\
\hline & yes & $20(35.7)$ & 56 & 0.19 & $0.06-0.6$ & 0.004 \\
\hline & no & $31(64.6)$ & 48 & & & \\
\hline \multirow[t]{2}{*}{ Diabetes: } & yes & $12(42.9)$ & 28 & 1.32 & $0.44-3.93$ & 0.6 \\
\hline & no & $39(51.3)$ & 76 & & & \\
\hline \multirow[t]{2}{*}{ Smoking: } & yes & $18(45)$ & 40 & 0.47 & $0.13-1.49$ & 0.2 \\
\hline & no & $33(51.6)$ & 64 & & & \\
\hline \multirow[t]{2}{*}{ Familial history: } & : yes & $32(53.3)$ & 60 & 2.43 & $0.83-7.10$ & 0.1 \\
\hline & no & $19(43.2)$ & 44 & & & \\
\hline \multirow[t]{2}{*}{ Hypertrophy: } & yes & $12(38.7)$ & 31 & 0.27 & $0.08-0.88$ & 0.03 \\
\hline & no & $33(51.6)$ & 64 & & & \\
\hline Severity 0 & & $7(58.3)$ & 12 & & & \\
\hline Severity 1 & & $7(58.3)$ & 12 & 0.74 & $0.11-5.02$ & 0.8 \\
\hline Severity 2 & & $18(56.3)$ & 32 & 0.77 & $0.15-3.87$ & 0.7 \\
\hline Severity 3 & & $23(46.6)$ & 50 & 2.49 & $0.48-12.93$ & 0.3 \\
\hline
\end{tabular}

\section{Discussion}

Better understanding of the pathophysiology of the clinical events of coronary atherosclerosis, recognition of the efficacy of primary and secondary preventive measures, and the introduction of new therapeutic managements have changed the evolution profile of ischemic heart disease.

In our study, prevalence of acute myocardial infarction as the first manifestation of ischemic heart disease was 49\%; the remaining $51 \%$ corresponded to chronic angina. In the literature, prevalence of chronic angina prior to infarction ranges from $25 \%$ to $50 \%{ }^{14-16}$. These differences may be attributed to diverse definitions of chronic angina and different populations studied.

Bechar et $\mathrm{al}^{6}$ reported the presence of angina prior to acute myocardial infarction in $43 \%$ of patients, in accordance with our study, in which angina prior to infarction was more common among hypertensive patients. However, the authors found a higher prevalence in females and diabetic patients. In addition, angina prior to acute myocardial infarction was a risk factor for higher in-hospital mortality and mortality 5 years after hospital discharge.

Our results showed that, except for hypertension, the remaining factors studied had no statistical significance in regard to ischemic heart disease presentation, even though the findings in the literature do not agree about this topic.

A cohort study ${ }^{6}$ conducted with 732 patients admitted to the hospital due to first acute myocardial infarction showed that $39 \%$ of the patients had no previous angina. Patients with previous angina were older, mainly females, and most frequently the previous acute myocardial infarction and postinfarction angina were early, being statistically significant. In-hospital mortality was similar in both groups, but in the 3 years following hospital discharge, it was higher in patients with previous angina ( $16 \%$ versus $7 \%)$. Another cohort study ${ }^{15}$, carried out with 587 patients, reported a $52 \%$ incidence of angina prior to infarction (in the preceding month). The study divided the patients into 4 groups as follows: no angina prior to acute myocardial infarction, chronic unstable angina, chronic stable angina, and angina of recent onset. No significant difference in sex and age was observed in the groups. Patients with chronic angina were more susceptible to developing infarction than patients with no previous angina (50\% versus $14 \%$ ). In-hospital mortality did not differ in the groups ${ }^{15}$.

Our study showed a greater incidence of ventricular hypertrophy in patients with previous angina. Therefore, we can conclude that the greater oxygen consumption by the ventricular mass was not satisfied because of the coronary artery obstruction, which caused the anginal symptoms.

In a study by Matsuda et $\mathrm{al}^{9}$, where the ventricular function of 31 patients with total occlusion of the anterior descending coronary artery and stenosis $<70 \%$ in any other coronary artery was assessed, 16 patients had no history of previous angina. Patients with angina prior to acute myocardial infarction showed better ejection fraction, a lower percentage of abnormalities in contractile segments and in regional motility of the cardiac wall, suggesting that previous angina contributes to preservation of postinfarction ventricular function ${ }^{7}$. Kobayashi et al ${ }^{17}$, however, reported that a worse long-term prognosis is associated with multiple-vessel coronary heart disease in patients with angina prior to infarction.

In conclusion, based on the findings of the present study, $49 \%$ of patients experiencing acute myocardial infarction do not have previous manifestations of coronary artery disease. This figure is close to those obtained in other studies, and it makes the clinical history of previous angina of little value for these groups. Patients with left ventricular hypertrophy and systemic arterial hypertension most frequently have angina prior to acute myocardial infarction; the other risk factors showed no participation in the acute myocardial infarction event with or without previous manifestations. This may result from the disparity between metabolic offer and demand in the presence of greater afterload.

\section{References}

1. Alexander RW. The coronary ischemic syndromes: relationship to the biology of atherosclerosis. In: Schlant RC, Alexander RW, O'Rouke RA, Roberts R, Snnenblick EH. Hurst's the Heart. $8^{\text {th }}$ ed. New York: Mc Graw-Hill, 1994: 1021-31.

2. Grundy SM, Pasternak R, Greenland P, Smith S, Fuster V. Assessment of cardio- vascular risk by use of multiple risk-factor assessment equations. Circulation 1999; 100: 1481-92.

3. Manfroi WC, Freitas FM, Gensini G, et al. Achados hemodinâmicos e cineangiocoronariográficos em pacientes acometidos de infarto do miocárdio: estudo com- 
parativo entre uma população de Syracuse, NY, USA, com outra de Porto Alegre, RS, Brasil. Arq Bras Cardiol 1980; 34:359-62.

4. Manfroi WC, Gensini GG, Kelly A. Achados hemodinâmicos e cineangiocoronariográficos em pacientes acometidos de infarto do miocárdio. Arq Bras Cardiol 1978;29:269-75.

5. Zucker DR, Griffifth JL, Beshansky JR, Selker HP. Presentations of acute myocardial infarction in men and women. J Gen Intern Med 1997; 12: 79-87.

6. Bechar S, Reicher-Reiss H, AbinaderE, et al. The prognostic significance of anginapectoris preceding the occurence of a first acute myocardial infarction in 4,166 consecutive hospitalized patients. Am Heart J 1992; 123: 1481-6.

7. Sullivan AK, Holdright DR, Wright CA, Sparrow JL, Cunningham D, Fox KM. Chest pain in women: clinical, investigative and prognostic features. Br Med J 1994;308: 883-6.

8. Pierard LA, Dubois C, Smeets J, et al. Prognostic significance of angina pectoris before first acute myocardialinfarction. Am JCardiol 1988;61:984-7.

9. Matsuda Y, OgawaH, Moritane K, et al.Effects of the presence or absence of preceding angina pectoris on left ventricular function after acute myocardial infarction. AmHeart J 1984; 108:955-8.
10. Sones FJ, Sinrey EK. Coronary arteriography. Mod Conc Cardiovasc Dis 1962; $31: 735-40$.

11. Judikins MF. Selective coronary arteriography: a percutaneous transfemural technique. Radiology 1967; 89: 814-19.

12. Bogaty $\mathrm{P}$, BreckerSJ, WhiteSC.Comparisonof coronary angiographicfindingsinacute and chronic first presentation of ischemicheart disease. Circ 1993; 87: 1938-46.

13. National Institute of Heath Consensus Development Conference Statment. National Instute Heath Consensus Development Panel on the Health Implication of Obesity. Ann Inter Med 1985; 103: 1073-7.

14. Midwall J, Ambrose J, Pichard A, Abedin Z, Herman MV. Angina pectoris before and after myocardial infarction: angiographic correlation. Chest 1982;81:681-6.

15. Harper RW, Kennedy G, DeSanctis RW, Hutter Jr AM. The incidence and pattern of angina prior to acute myocardial infarction: a study of 577 cases. Am Heart J 1979; 197: 178-83.

16. Solomon HA, Edwards AL, Killip T. Prodromata in acute myocardial infarction. Circulation 1969; 40: 463-71

17. Kobayashy Y, Miyazaki S, Miyao Y, et al. Effects on survival of previous angina pectoris after acute myocardial infarction. Am J Cardiol 1997; 79: 1534-8.

Mevalotin (pravastatina) - Informações para prescrição (resumidas)

Contra-indicações: Pacientes com hipersensibilidade a qualquer componente da fórmula; Distúrbio hepático ativo ou elevações persistentes, não explicadas, nos testes de função hepática; Gravidez ou lactação. Descontinuar a terapia com a pravastatina caso ocorra gravidez. Precauções: Deverão ser realizados testes de função hepática periodicamente, pois os inibidores da HMG-CoA redutase foram associados com alterações bioquímicas da função hepática. Caso ocorra aumento persistente das transaminases (ALT e AST) igual ou superior em três vezes o limite superior normal, a terapia deverá ser descontinuada. Em pacientes com histórico de doença hepática ou de grande ingestão alcoólica recomenda-se monitorização mais intensa quando a pravastatina for administrada. Musculatura Esquelética: Mialgia, miopatia e rabdomiólise foram relatados com o uso de inibidores da HMG-CoA redutase. Casos de mialgia não-complicada foram raramente relatados em pacientes tratados com a pravastatina, com uma incidência similar à do placebo. Rabdomiólise com disfunção renal secundária à mioglobinúria também tem sido relatada devido à pravastatina, embora muito raramente. Pacientes deverão ser alertados para relatar imediatamente dor, amolecimento ou enfraquecimento musculares inexplicáveis. A terapia com a pravastatina deverá ser descontinuada se ocorrerem aumentos acentuados dos níveis de CPK ou se houver suspeita ou diagnóstico de miopatia (definida como dor ou fraqueza muscular associada a aumento nos valores de creatinofosfoquinase - $\mathrm{CPK}$ - acima de 10 vezes o limite superior normal). $\mathrm{O}$ risco de miopatia durante o tratamento com outros inibidores da HMG-CoA redutase é maior com a terapia concomitante com fibratos, ciclosporina, eritromicina ou niacina. Em um estudo clínico de tamanho limitado, não foi relatada miopatia com a terapia combinada pravastatina (40mg/dia) e genfibrozil (1200 mg/dia), embora tenha sido observada tendência para elevações de CPK e sintomas musculoesqueléticos. Contudo, o uso combinado de pravastatina e fibratos deverá ser evitado. Não foi observada a ocorrência de miopatia nos estudos clínicos com 100 pacientes pós-transplantados $(24$ renais e 76 cardíacos) tratados concomitantemente com pravastatina $(10-40 \mathrm{mg})$ e ciclosporina por até 2 anos, sendo que alguns foram submetidos também à terapia com outros imunodepressores. Além disso não houve relatos de miopatia nos estudos clínicos envolvendo pequeno número de pacientes tratados com a pravastatina juntamente com a niacina. Hipercolesterolemia Homozigótica Familiar: A pravastatina não foi avaliada em pacientes com hipercolesterolemia homozigótica familiar de incidência rara. Lactação: Mães em terapia com Mevalotin (pravastatina) não deverão amamentar. Uso Pediátrico: A segurança e efetividade em crianças e adolescentes, com menos de 18 anos de idade, não foi estabelecida. Portanto, o tratamento com Mevalotin (pravastatina) não pode ser recomendado para este grupo etário. Interações Medicamentosas: Colestiramina Colestipol: Não houve diminuição clinicamente significante da biodisponibilidade ou do efeito terapêutico quando a pravastatina foi administrada uma hora antes ou quatro após a colestiramina ou uma hora antes do colestipol e uma refeição normal. A administração concomitante resultou em redução de $40 \%$ a 50\% da AUC média da pravastatina. Ciclosporina: Níveis plasmáticos da ciclosporina em pacientes sob tratamento com pravastatina, não indicam aumentos clinicamente significativos nestes valores. Em estudo de dose única, os níveis plasmáticos da pravastatina estavam aumentados em pacientes cardíacos transplantados recebendo ciclosporina. Varfarina: A pravastatina não teve efeito clinicamente significante sobre o tempo de protrombina quando administrada em um estudo de pacientes idosos normais que foram estabilizados com a varfarina. Outros fármacos: Uma terapia de associação com um ou mais agentes complementares redutores de lipídios pode ser necessária em alguns pacientes. Ao contrário da maioria dos inibidores da HMG-CoA redutase, a pravastatina não é significantemente metabolizada pelo citocromo P450 3A4. Estudo de interação farmacocinética com ácido acetilsalicílico, antiácidos (uma hora antes de Mevalotin), ácido nicotínico, probucol, gemfibrozil e cimetidina não demonstraram alteração na biodisponibilidade com a administração de Mevalotin (pravastatina). Nos pacientes tratados simultaneamente com resinas fixadoras de ácidos biliares, Mevalotin(pravastatina) deve ser administrado 1 ou mais horas antes, ou 4 horas após uma dose de resina. O clearence de antipirina pelo sistema citocromo P450 permaneceu inalterado pela administração de Mevalotin (pravastatina). Durante ensaios clínicos não foram relatadas interações medicamentosas perceptíveis quando Mevalotin (pravastatina) foi administrado com diuréticos, anti-hipertensivos, digitálicos, inibidores da enzima conversora, bloqueadores dos canais de cálcio, betabloqueadores ou nitroglicerina. Reações adversas: Em dois estudos controlados com placebo, o perfil de segurança e tolerabilidade no grupo da pravastatina foi comparável ao do grupo placebo em mais de 10.754 pacientes tratados por mais de $4,8-5,9$ anos (média). Os seguintes eventos adversos foram relatados por mais de $2 \%$ dos pacientes de estudos controlados com placebo de até $4 \mathrm{meses}$ de duração, independentemente da etiologia: Musculatura esquelética: Dor musculoesquelética localizada, mialgia; Gastrintestinais: Náuseas/ vômitos, diarréia, constipação, dor abdominal, flatulência; Respiratórias: resfriado comum, rinite; Neurológicas: Cefaléia, vertigem; Gerais: Fadiga, dor no peito (não cardíaca); Dermatológicas: Erupção cutânea; Cardiovasculares: Dor no peito. Cristalino: Durante o tratamento por períodos de um ano ou mais, 820 pacientes tratados com pravastatina não revelaram evidências relativas ao aparecimento de catarata. Posologia: O paciente deverá ser submetido a uma dieta redutora de colesterol antes de iniciar a terapia com Mevalotin (pravastatina), que deverá ser mantida durante o período de tratamento. A dose recomendada é $10 \mathrm{mg}$ a $40 \mathrm{mg}$ uma vez ao dia, independente das refeições, de preferência à noite (pois parece ser ligeiramente mais efetiva do que a dose única pela manhã). A posologia diária também pode ser administrada em doses divididas. Superdosagem: A experiência sobre a superdosagem de pravastatina é limitada. Até o momento, há relato de dois casos, que foram assintomáticos e não associados a anormalidades em testes clínicos laboratoriais. Pacientes idosos: O produto poderá ser usado por pacientes acima de 65 anos de idade, desde que observadas as precauções comuns ao medicamento.

Registro no MS n. 1.0454.0047 